\title{
The Limits of Liberal Tolerance (postprint)
}

Final version appears in Public Affairs Quarterly 29 (2015): 277-95

\section{Thomas Mulligan}

A central challenge for liberalism is to provide a satisfying account of tolerance. Such an account is practically necessary as liberal states search for solid theoretical footing in their relations with illiberal states. The illiberality of these states, of course, comes in degrees. North Korea provides virtually no social or political rights for its citizens and regularly uses kidnapping, torture, and murder to enforce the people's compliance. Turkey, on the other hand, has established a range of substantial, constitutionally-protected liberal rights.

The liberal must explain why the conduct of North Korea is intolerable and how the international liberal community ought to express its intolerance. The liberal must also decide if Turkey's much less pernicious conduct is intolerable as well —and, if so, how that intolerance ought to be expressed (presumably in a far more modest way than the expressions of intolerance against North Korea).

Whatever the difficulties of answering these questions about tolerance among states are, liberalism faces a unique and deeper challenge. It is often argued (by, most notably, Isaiah

Berlin) ${ }^{1}$ that pluralism — the idea that moral goods are multiple — is an essential element of liberal theory. Pluralism suggests that we ought to tolerate a wide range of behavior, but what should we do with behavior that is illiberal in character? This question points to a potential inconsistency in liberal theory; does liberalism's insistence on, for example, freedom of speech elevate that principle to a preferred moral status which is incompatible with pluralism? These 
are foundational questions and closely connected to the problem of tolerance toward illiberal states. The issue that I am ultimately interested in is whether liberalism's commitment to human rights abroad is at odds with its avowed need to respect the diversity of moral opinion, but that issue must be addressed through a broader analysis of liberalism and pluralism.

In this essay I do two things. First, I elucidate the connections between tolerance, liberalism, and pluralism. We cannot answer questions about tolerance of illiberal regimes until we have solved the puzzle of how to reconcile liberalism with pluralism. Second, I argue that this puzzle can be solved by carefully distinguishing the responsibilities of liberal states to their peoples from the responsibilities of liberal states to other states. It is true that liberal states must tolerate pluralistic plans-of-life, some of which will be "illiberal". But liberal states should not tolerate states that fail to provide the conditions necessary for their citizens to live their lives as they see fit, in "liberal" ways, "illiberal" ways, or otherwise. States have a responsibility to enable pluralism within their borders, and the states that do — that is, liberal states — should not tolerate states that do not.

\section{The Concept of Tolerance}

To tolerate something is to refrain from intervening against it. Additionally, "toleration" connotes disapproval; we do not say that we tolerate charitable giving, although that is certainly not something against which we intervene. ${ }^{2}$ While disapproval is essential to cases of tolerance, it not essential that the disapproval be moral in character. Jones tolerates his tattoo when he disapproves of it on aesthetic (i.e. non-moral) grounds yet decides against having it removed. Toleration is a contextual phenomenon which takes on moral aspects only in certain contexts. 
In addition to disapproval, cases of tolerance consist of two essential elements. First, the agent exercising tolerance must possess the power to act against the disapproved-of thing. Absent this power we do not speak of the agent's "tolerance" but rather his "acquiescence". 3 Second, the agent has some grounds to refrain from intervening. The crucial point here is that in cases of tolerance, the agent refrains from intervening because the bad behavior (e.g.) is trumped by some greater evil associated with the proposed intervention.

This greater evil can come in one of three forms. First, it could be that the means of intervention is worse than the tolerated thing. While the sound of squirrels scurrying around my attic is irritating — a bad thing — if the only available intervention is lethal squirrel traps, I might tolerate the noise because its badness is trumped by the greater badness of killing squirrels.

Second, though the means of intervention might be unobjectionable, it could produce a secondary effect worse than the tolerated thing. Imagine a family which invites a racist relative to its annual Christmas dinner. The family disapproves of the relative's views and has an unobjectionable means of intervening against him (viz. not proffering an invitation). Yet the family might decide to tolerate the relative's presence on the grounds that he is depressed and liable to become more so if he is not invited. The relative's depression trumps his offensiveness.

Third, there are cases of tolerance that turn neither on the severity of the means of intervention nor on the secondary effects of intervention, but rather on the idea that intervention is wrong in itself. These are the archetypical cases of political tolerance. For example, "hate speech" is widely tolerated in the United States. We can imagine a case in which some hate speech could be curbed through an inoffensive means with no ill secondary effects. In this case we might still be inclined to tolerance on the grounds that any intervention would violate a right to free speech. And however bad hate speech is, it is not as bad as violating a right. This 
explains cases in which someone is acting in a morally blameworthy way but yet we ought not to intervene against him; indeed, intervention would itself be blameworthy. The person spouting hate speech is doing something bad, to be sure, but he is protected from intervention by a higherorder moral consideration — namely, his right to free speech.

I cannot give a full conceptual analysis of tolerance here, ${ }^{4}$ but there are three points worth keeping in mind for the remainder of this essay. First, when we decide that we can no longer tolerate some person, government, or nation, we ipso facto mean that intervention ought to take place. While we, qua individuals, may not be obliged to intervene (not least because we lack the power to do so), the fact of our intolerance implies that there is some responsible community that can, and should, intervene against the bad behavior.

Second, intolerance does not require that the responsible community completely curb the offending behavior. Intolerable behavior may be permitted to continue so long as intervention is taking place. Trainers tell us not to tolerate our dogs' jumping on visitors. Yet this intolerable behavior is not grounds for euthanizing the animal. That remedy would indeed end the behavior, but it would be inappropriate given the minor nature of the offense. Stern words and obedience training are the correct means of intervention, even though they will not fully curb the behavior, at least in the short term. The moral obligation generated by intolerable behavior is simply that the responsible community take measures to correct the behavior. It is not necessary that these measures achieve, or even attempt to achieve, an immediate and complete cessation of the behavior. The degree of offense will dictate the degree of intolerance and, in turn, the remedy. Third, although expressions of intolerance will sometimes aim to punish, that is not an essential component of intolerance. In the case of the rambunctious dog, neither stern words nor obedience training qualify as punishment. This points to the often rehabilitative nature of 
intolerance, especially evident when offenses are minor. In cases of minor offense we are less concerned about the deterrent effects of our expressions of intolerance or about visiting retribution upon the offender; rather, we are intolerant as part of a peaceful effort to persuade the offender to reform his ways. That said, in cases of seriously intolerable behavior-murder, for example - expressions of intolerance are forms of punishment, designed to deter, penalize, and incapacitate.

\section{Liberalism, Pluralism, and the Incompatibility Challenge}

The core tenet of liberalism, to my mind, is respect for individual choice. Persons should be at liberty to pursue the lives they want and engage in the activities they desire, subject to reasonable limits which are generally necessary to assure the liberty of others. William Galston puts it this way:

liberalism requires a robust though rebuttable presumption in favor of individuals and groups leading their lives as they see fit, within a broad range of legitimate variation, in accordance with their own understanding of what gives life meaning and value. ${ }^{5}$

This individual choice can be protected, politically, through a range of social and political rights, such as freedoms of speech, religion, and free association.

The liberal ideal might seem to naturally jibe with pluralism (sometimes "valuepluralism”), which affirms a multitude of moral goods. ${ }^{6}$ Pluralists reject the monistic claim that there is a single, ultimate good which the various other "goods" serve instrumentally. According to Sterling Lamprecht (who prefigured interest in pluralism by five decades), ${ }^{7}$

the goods available to us in this world in which we find ourselves are widely various, often incompatible, and in many cases incommensurable, and that consequently the choices which in practise we are forced to make are rather personal options than discoveries of eternal principles. ${ }^{8}$ 
Among other things, pluralism is a common sense extrapolation from our everyday experience. People simply do put different priorities on values in their lives, and it is not obvious how we might rank these priorities even if it were desirable to do so.

The definition of pluralism typically consists in the following three components: First, there are multiple moral goods which can neither be reduced to a single summum bonum nor rank-ordered. Second, these multiple moral values can come into conflict. And third, there is no rational method to adjudicate these conflicts.

The intuitive sense in which liberalism and pluralism are happy bedfellows has to do with tolerance. If pluralism is true then states plausibly have a moral obligation to be tolerant of the diverse lifestyles which reflect the diversity of moral goods and the many ways we might pursue them. States must tolerate unpopular lifestyle choices, moral views contrary to the prevailing ethic, and various forms of cultural dissent. Liberal states do just this. Pluralism demands tolerance and liberalism is the political system that provides it. The idea that liberalism and pluralism are closely connected found its most famous exposition in the work of Isaiah Berlin, and it continues to be defended by contemporary philosophers. ${ }^{9}$

Some philosophers believe, however, that not only does pluralism not imply liberalism, the two concepts are in fact incompatible. John Gray is the leading proponent of this view, arguing that the true implication of pluralism is that liberalism is merely one among a multitude of legitimate political doctrines. ${ }^{10}$

The argument against the compatibility of liberalism and pluralism proceeds as follows: First, it is observed that archetypically "liberal" values are just a few of the diverse goods recognized by pluralism. There is nothing special about them. Liberty in personal conduct may well be a bona fide value, but if so, and if pluralism is true, then it will sometimes come into 
conflict with "illiberal" values. In these cases we cannot say which takes priority, which is "more valuable"; goods cannot be ranked in that way. Pluralism demands that liberty, personal expression, and the other archetypical "liberal" values not be elevated to any special status.

Second, because "no political morality can be sealed off from conflicts of goods",, liberal states cannot be held up as moral exemplars. To say that liberal democracy is a preferred form of government is to say that liberty is a preferred good. But that is expressly what pluralism denies. Pluralism demands, the argument goes, that some illiberal states be considered of equal moral standing:

a non-liberal regime which protects its citizens against the Hobbesian evils of crime and civil strife by limiting freedom of religion may not be better or worse than a liberal regime in which religious freedom is protected but citizens are unsafe from crime and civil disorder. ${ }^{12}$

On this view, liberal governments are just one type of morally legitimate political entity. Other legitimate political entities are based on "illiberal" values. Since pluralism demands that some "illiberal" values be given equal moral weight to "liberal" values, this in turn implies that the overlying political entities are equally legitimate.

The crucial move here, and where the argument goes awry, is from (1) denial that personal liberty holds a preferred status to (2) denial that liberal government holds a preferred status. Pluralism does not extend into politics. Liberal states do not exist to encourage "liberal" plans-of-life nor to elevate "liberal" goods to a preferred status. Instead, liberalism provides the minimal conditions necessary for citizens to pursue various plans-of-life—some "liberal", some “illiberal", and some in-between. Illiberal political entities fail to provide the conditions necessary for their citizens to pursue some legitimate plans-of-life and are therefore unjust. Only liberal governments show proper regard for pluralism. 
We should accept the first step of the argument — that there is nothing special, morally, about "liberal" values. A person who embodies liberalism, whatever that means, is not morally superior to someone who embraces a conservative lifestyle. But we should reject the second step of the argument - that somehow this moral equality flows through persons and into states.

\section{Pluralism Implies Liberalism}

Liberalism should be understood as a regulative political doctrine designed around true moral principles, one of which is pluralism. If pluralism is true, then it puts constraints on our politics, forcing them to be liberal in character. This view falls within the tradition of Charles Larmore and Rawls, in which liberalism is fundamentally a political doctrine which need not take a stand on conceptions of the good life. ${ }^{13}$ As Eric Mack puts it,

liberty plays a distinctive normative role . . it is a principle that regulates the pursuit of substantive values by individuals and groups. Liberty serves as the core norm of a public framework within which individuals and groups are free to pursue their respective and distinctive ends and commitments subject only to their according a like freedom to others. ${ }^{14}$

A just political system gives its citizens wide latitude in arranging their lives as they see fit. It is, in short, liberal. Illiberal political arrangements - that, say, discriminate against some religious minorities_-put constraints on persons' morally acceptable behavior (their devotion to their religion), and that is unjust. That the members of an oppressed minority could pursue alternate routes to moral goods (i.e. they could devote themselves to the state religion), while true, does not render the system just. The system encroaches on the moral space carved out by pluralism. Since our politics must conform to our morality, if pluralism is true then states must make space for the many paths-of-life that a person may justly pursue. 
I have been using scare quotes when referring to "liberal" values because strictly speaking these do not exist (I'll dispense with the scare quotes from here on out). There are, to be sure, values and lifestyles that we typically associate with proponents of liberalism. We speak offhand, for example, of freedom as a moral good. But in fact freedom and the other liberal principles stand a category apart from the goods; they are political principles. As Larmore puts it, "liberalism is not a philosophy of man, but a philosophy of politics". 15

Although Gray and his allies correctly view liberalism as a political doctrine, they incorrectly regard its constitutive elements as members of the class of plural moral goods. And the argument that they seek to make against the pluralism-to-liberalism implication turns crucially on this misidentification. Gray says, for example, that

the principles of liberal morality acquire a definite application only insofar as they regulate specific goods. Each of these goods-negative liberty, personal autonomy, or whatever-itself generates conflicts among incommensurables. $^{16}$

But negative liberty and personal autonomy are not moral goods. They are, rather, overlying political doctrines which are morally necessary owing to the diverse ways that moral goods may be pursued. As pluralists, we want to say that the conservative Muslim and the social justice activist are both pursuing legitimate plans-of-life in accordance with their own conceptions of the good. And as liberals we want governments to enable and protect these different lifestyles. There cannot be a conflict between (1) religious devotion/radical activism and (2) negative liberty/personal autonomy because (1) and (2) stand a category apart. Category (1) contains the plural moral goods and plans-of-life, and category (2) contains the political doctrines necessary to protect the diversity of (1).

One can easily imagine a life centered on religious devotion or radical activism; someone adopting religious devotion as a good would look like a monk and someone adopting radical 
activism would look like an Occupy Wall Street protester. But what on Earth would a life centered on negative liberty look like? Or a life centered on personal autonomy? It is like asking what a life centered on strategic nuclear deterrence looks like; that is not a moral good but a political choice made necessary (some would argue) by moral considerations. These concepts — negative liberty, personal autonomy, and strategic nuclear deterrence — simply stand a category apart from religious devotion, radical activism, and other legitimate plans-of-life. ${ }^{17}$

This is not to say that personal autonomy, liberty, equality, and the other components of liberalism are not special from a moral point-of-view. They are. But they are special only at the political level, as the just principles around which the state must be structured. Consider George Crowder's claim that "we have no reason, as pluralists, not to prefer order and hierarchy to liberty and equality". ${ }^{18}$ This sentence may be interpreted in two ways, and under one interpretation it is true and under the other it is false. It is true when interpreted at the intrastate level, as a claim about the variety of goods adopted by persons within national boundaries. If we assume that there is a sense in which liberty, equality, order, and hierarchy are in fact moral values, pluralism denies that any rank-ordering of them is possible. Accordingly, any preference is a matter of taste and cannot be said to be morally superior or inferior to other legitimate preferences. So on this interpretation Crowder is correct, but on a second interpretation he is wrong. We do, as pluralists, have reasons to prefer political systems based on liberty and equality to systems based on order and hierarchy. This preference is in fact born out of the first interpretation of Crowder's claim. If moral values are in fact plural, then governments cannot place special restrictions on their citizens, be they liberal or illiberal, according to historical or prevailing norms. Those restrictions would ignore the demands of pluralism by constraining 
certain legitimate paths-of-life. There is a range of restrictive conduct in which governments cannot justly engage. ${ }^{19}$

My argument would not sway those who believe that there is something incoherent about the notion that some political entities do a better job than others in carving out space for pluralistic plans-of-life:

When we judge that one society or person is freer than another we are presupposing a ranking of human interests which articulates a particular conception of wellbeing. ... Liberty cannot be measured because the interests that are opened or closed by different options are often incommensurate. It cannot be maximized because what counts as the greatest liberty varies with different conceptions of the human good. ${ }^{20}$

The idea seems to be that the religious conservative who lives in an illiberal country that supports her theological leanings is "freer" than a religious conservative in a liberal state in which the prevailing ethic is contrary to her beliefs. But that is not correct; judgments about freedom are not moral but empirical. When we judge that a person is freer we presuppose nothing and rely on empirical investigation: How many distinct plans-of-life can this person pursue under the regime? Does she have a fair right of exit from the illiberal group she is a member of? What happens to her if she changes her mind? Now, it certainly may be the case that she is happier and more comfortable in the illiberal society. She might not be able to flourish in a liberal society as she could in an illiberal one (importantly: an illiberal society that just happened to cohere with her views). The religious conservative might be worse-off in a liberal society. But she would still be freer in one. There is no impediment to making empirical judgments about which political systems best enable diverse ways of life.

Although pluralism requires that we remain neutral about how a person ought to find meaning in her life, this neutrality is not tantamount to indifference about moral matters. Our politics can simultaneously (1) maintain the neutral posture toward the good life that is mandated 
by pluralism, and (2) constrain and enable bad and good behavior, respectively, on the basis of moral principles. Although some will claim that this is impossible - we are not, they will say, remaining neutral when we prevent someone from committing murder as part of her chosen planof-life- they are wrong, for violence is not a moral good.

Compare the question "what makes for good art?" Some people say that it's verisimilitude; some say the ability to evoke emotion; and others, pure, visceral, aesthetic impact. I am neutral on this question (mostly because I don't know the first thing about art). But I recently finished a drawing of a robot wearing a top hat, and let me assure you: it is not good art. Now, just because I've weighed in on the demerit of my doodle doesn't mean that I've abdicated my aforementioned neutrality. No: I can continue to be neutral on what makes art good while ruling out some obviously false possibilities. Similarly, I, as a liberal, can remain neutral on the question of what makes a life go well while saying, reasonably and with confidence, that it's not theft, rape, or murder.

The fact that liberalism constrains plans-of-life that include murder is unproblematic because murder — we all agree — is morally bad. And the fact that some liberal governments constrain some behavior (e.g. prostitution) that other liberal governments do not is also unproblematic, since there is reasonable dispute over the morality of prostitution. These borderline cases need not concern us. We need to be concerned, rather, when a government seeks to constrain plans-of-life that we know are legitimate. We need to be concerned, that is, by illiberal politics.

What of the charge that some legitimate plans-of-life can only be realized within illiberal political societies? If that were true then it would present a problem for the argument that I have given. But it is false. These illiberal forms of life can be maintained while ensuring that citizens 
are not prohibited from arranging their lives as they see fit. The political practices that liberals object to - namely, the practices that constrain a person from pursuing legitimate plans-of-lifecan be eradicated without destroying the underlying illiberal culture. Consider the practice of female genital mutilation (FGM), much-discussed in the literature on global justice. Liberals are right to condemn societies that impose this practice on their girls (mostly certain African ethnic groups). Why? Because they deprive their victims of all plans-of-life arranged around the genuine moral good of sexual pleasure. So we should eradicate the (political) practice. We can do so without destroying the underlying culture. This is possible because FGM is not essential to the culture; what is essential is that the group have some cultural practice(s) to unite it. And there are viable alternatives that do not violate the moral demands of pluralism as FGM does. Indeed, some non-governmental organizations such as Maendeleo Ya Wanawake have worked to develop and implement an alternate rite of passage to replace FGM, thus eradicating an unacceptable practice while maintaining the integrity of the underlying culture. ${ }^{21}$

An implication of my argument is that we must remove, to some extent, the political category from what a good life can consist of. No one may rightly object, for example, that his plan-of-life is infringed upon by liberal justice because it includes living under a conservative political system. Such a plan-of-life is morally illegitimate, since living under conservative politics is not one of the plural moral goods. Pluralism is not relativism, nor is it carte blanche to develop plans-of-life that include the "value" of imposing one's will on one's peers.

I turn now to address the second major error made by Gray's camp: the suggestion that liberal political systems are, by their nature, putting forth liberalism as a preferred value. That does not follow. Liberal tolerance requires that space be made for a wide range of plans-of-life. If some persons want to comport themselves in an illiberal fashion-as religious conservatives, 
for example - that is their affair, provided they are making free choices to do so. ${ }^{22}$ The moment, however, that the conservative shifts his sights from liberal values and lifestyles to liberal justice is the moment that, if we are to take pluralism seriously, our tolerance ought to end.

The belief that when we put forth liberalism as a preferred political doctrine we are perforce preferring liberal values leads Gray and others to conclusions which are plainly false. Consider Gray's assertion that pluralism "rejects the claim that the human good can be fully realized only in a liberal regime". ${ }^{23}$ Pluralism is right to reject that claim, but liberals should reject it too, and so there is no tension. Liberals can concede that the human good can be fully realized in illiberal states - the devout Muslim living in illiberal Saudi Arabia flourishes, no doubt about it. He finds no barriers to his lifestyle there. But his flourishing is not due to political justice but the mere accident of living under a government that happens to agree with his views. In his country, liberals (and conservatives who do not agree with the prevailing morality) are unable to pursue their plans-of-life in accordance with the goods that they find meaningful. The demands of pluralism are violated. This is not the case in liberal states, where a religious conservative does not have to benefit from good luck to flourish. Instead, he moves within the domain of reasonable freedom that the government has carved out for him to practice his religion without impediment.

My account of the liberalism-pluralism connection sheds light on the way we ought to justify liberal protections such as equal rights for women. These rights are necessary to protect a woman's ability to choose a plan-of-life. If a free woman decides to subjugate herself to a man for religious reasons (i.e. pursue an illiberal lifestyle), liberalism poses no objection except to say that she must be free to make that decision for herself. There is a crucial moral difference 
between (1) a person who has a conservative lifestyle forced upon her by an illiberal government, a lifestyle which, by pure luck, she happens to enjoy; and (2) a person who, in a liberal society, freely elects a conservative plan-of-life.

These considerations illuminate flaws in other arguments that seek to deny the implication from pluralism to liberalism. Consider Richard Arneson's contention that

if there are plural values and no ranking of them can be defended, then one cannot claim that in organizing society to maximize the single value $X$, one is maximizing what is best. But equally no one can object to making $X$ the politically privileged value on the ground that better outcomes would be obtained if we let a thousand flowers bloom. ${ }^{24}$

Fair enough. But we can object to making $X$ the politically privileged value on other groundsnamely, that that would fail to take pluralism seriously. Imagine a world consisting of two liberal states, Diversityville and Homogenousburg. They are politically identical but culturally quite distinct: in Diversityville a thousand flowers do bloom, the citizens live a variety of interesting and dissimilar lives — in short, it is a liberal's paradise. In Homogenousburg this is not the case- the people are monolithic conformists. If the two states are acceptably liberal (which, ex hypothesi, they are) then Arneson is right—pluralism demands that we consider them of equal moral standing. Homogenousburg might strike us as dull and inferior, but that intuition is a result of our prejudice against conservative plans-of-life; it is not a reflection of a moral fact.

But now let us imagine that Diversityville's government is overthrown. The new administration makes few changes except to outlaw and crack down on a troublesome religious minority. With that exception, Diversityville remains the heterogeneous place it always was. Now there are two true things that can be said about this new world. First, Homogenousburg is a more just state. The political system there is in full liberal compliance. Homogenousburg's politicians are taking pluralism seriously, as evidenced by the fact that they have established the 
necessary conditions for the full variety of plans-of-life to be pursued. The fact that all of Homogenousburg's citizens have decided on the same plan-of-life is irrelevant. Second, for reasons that I will explain in $\S 4$, Homogenousburg's leaders should not tolerate Diversityville, which, in its minor illiberalism, is erring morally. As I suggested in $§ 1$, the mere fact of intolerance does not justify an invasion of Diversityville. But it is a striking result that liberals are obliged to regard Homogenousburg as the just state and Diversityville as the unjust one.

Along similar lines, we should reject Bernard Williams’s claim that if there are many and competing genuine values, then the greater the extent to which a society tends to be single-valued, the more genuine values it neglects or suppresses. More, to this extent, must mean better. ${ }^{25}$ While it is true that a single-valued society "neglects" other legitimate values, it does not follow from this that the single-valued society is inferior. More does not mean better. A society that throws its lot in with one or two values, as Homogenousburg does, is the moral equal of more diverse societies. Gray seems to agree with Williams here, ${ }^{26}$ but this is an odd view for the pluralist to hold. For if moral values are incommensurable then we have no reason to long for a diverse world. If of two sisters one decides to be a doctor, pluralism does not tell us to encourage the second to avoid a career in medicine in the name of producing a more diverse world. Pluralism only tells us that there are other paths-of-life which she can elect if she desires. Diversity has no intrinsic moral value, although it is good evidence that our politics are responding appropriately to something that is of intrinsic moral importance-namely, pluralism.

A last-ditch move is to try to fulfill the political demands of pluralism through a diversity of illiberal states. Maybe 200 distinct illiberal countries, the argument would go, are just as good as 200 liberal democracies. The former situation provides the opportunity to pursue distinct plans-of-life, an opportunity which pluralism demands that we have, so why not consider it the 
moral equal of a uniformly liberal world? This response fails for two reasons. First, the problems related to migration and national sovereignty are legion, and for such a system to adequately respect pluralism we would need a world without borders, where a person could freely resettle in the illiberal state that matched her plan-of-life. To say that this is a dubious prospect is an understatement. Second, there is no guarantee that 200 illiberal states (or however many) would suffice to recognize the various legitimate plans-of-life. People choose diverse and sometimes oddball purposes for their lives. Pluralism tells us that they are justified in doing so, and no matter how many illiberal states we have it won't be enough to capture that range of personal choice. But a single liberal state can do it without difficulty.

\section{Illiberal States Should Not Be Tolerated}

Any just political arrangement must recognize the truth of pluralism by protecting the plans-oflife chosen by individuals in pursuit of the moral goods that they consider important. Only liberal political systems do so, by adopting a stance of neutrality about how their citizens find meaning in their lives. Illiberal systems, on the other hand, wrongly proscribe some legitimate plans-of-life, by either (1) adopting certain moral goods as the core values of the state and pushing them on their citizens (i.e. violating moral pluralism), or (2) preventing citizens from pursuing goods as they reasonably see fit (violating political pluralism). Although frequently the plans-of-life promoted by illiberal governments are genuine ones, and a person might freely choose one of these on his own, no government can justly force them upon its citizens. Governments are instead obligated to provide the conditions necessary for each individual to form and pursue the plan-of-life that he thinks best. 
This result, while interesting, does not itself provide the conclusion that the international community ought not to tolerate illiberal states. But this conclusion is readily yielded in light of the conceptual analysis of tolerance given in $\S 1$. We recall that tolerance may be extended to bad conduct only if one of the following conditions obtains: (1) the means of intervention is worse than the tolerated thing; (2) there are worries about the secondary effects of intervention; or (3) within a given context intervention is intrinsically wrong.

None of these conditions obtains; therefore, illiberal states should not be tolerated. (3) can be easily disposed of: there are plenty of examples of just intervention against illiberality, and so intervention cannot be intrinsically wrong. Economic sanctions against North Korea are one such example. And it is clear that (1) and (2) do not pose a danger when we recall, from $\S 1$, that our expressions of intolerance need not eliminate - nor even be intended to eliminate - the objectionable conduct. We must only reasonably expect that they will have a productive effect.

We also recall that our expressions of intolerance cannot be disproportionately harsh. This reflects what I suspect is a near-universal intuition among liberals that mildly illiberal states like Turkey are simply not acting intolerably enough to warrant military intervention. Even if we knew that military intervention would effectively change the Turkish government into a fully liberal one, and even if we knew that this would come with no loss of life or other negative consequences (perhaps we knew that the Turkish government would immediately surrender), it would still be unjust to invade Turkey. States that have made good-faith efforts to liberalize-in Turkey's case against strong headwinds of religious fundamentalism — are owed our respect even as we continue working against their remaining intolerable elements through mild intervention. To say that the international community must not tolerate illiberal states is only to say that it is morally obliged to take measures, not unduly harsh, to improve the behavior of these states. 
This is not to say that illiberal states can never be tolerated, as a conceptual matter. Of course we can conjure up a scenario under which one of the conditions of $\S 1$ obtains and we become morally obliged to tolerate illiberality. The point is that the tolerance that pluralism requires us to show toward the diversity of plans-of-life does not extend to illiberal governments. There is a direct implication from pluralism to domestic tolerance, but there is no implication from pluralism to tolerance at the international level. In fact, intolerance at the level of international politics is necessary to protect pluralism and its call for domestic tolerance. For this reason, liberal states (but not liberal values) can truly be said to be better than illiberal states. Liberalism is not on a mission to perfect the world's peoples in its own image. It does not seek to create a universal condition of liberal actors but rather to establish the minimal conditions of freedom so that pluralistic ways of life can flourish.

The view presented in this essay is one that is notably rejected by Rawls, and so I wish to devote a little space to illuminating where Rawls goes wrong. In The Law of Peoples, Rawls argues that a small class of illiberal peoples should be tolerated. For Rawls, tolerance is restraint from using political sanctions, of which he specifically identifies "military, economic, [and] diplomatic" 27 intervention. But those are not the only ways to express intolerance. They are perhaps the strongest and most effective means, but, as pointed out in $\S 1$, the definition of intolerance provides that the strongest and most effective means are not always appropriate. Modest illiberality should be met with modest intolerance. Turkey is clearly not deserving of military intervention. Nor (unlike North Korea), does it deserve economic sanctions. But those are not the only options available to the international community. Personal, non-diplomatic messages of disapproval among liberal leaders and Turkish officials play a role in making the case for liberalism, and the promise of increased foreign aid and closer relations with fully liberal 
states is also a motivator. Perhaps most important in the Turkish case, a desire to participate in institutions like the European Union can promote liberalization. These are subtle but real expressions of intolerance.

Rawls's archetypically tolerable illiberal state is what he calls a "decent consultation hierarchy”. Rawls's fictional example of a decent consultation hierarchy, Kazanistan, is a state in which dissent is respected, there is a fair and effective bureaucracy and judiciary, and many social and political rights are protected. Nevertheless, there is no separation of church and state and high office is open only to Muslims. One straightforward objection to Rawls is that his notion of tolerable illiberalism is simply unrealistic (Rawls anticipates this objection and rejects it). ${ }^{28}$ In any case, Rawls concedes that Kazanistan is not perfectly just, and therefore at least open to criticism. But given that on my account criticism itself can be a form of intolerance, Rawls's tolerable decent consultation hierarchies are theoretical excrescences. We should instead say that they, too, should not be tolerated, but that, since Kazanistan is a pretty decent place, the liberal intervention is likely to be modest. Liberal states may work in a peaceful manner to liberalize Kazanistan but they may not go to war to do so.

My account has the benefit of capturing Rawls's desire to criticize decent but illiberal peoples in a simpler way. It seems implausible that, whatever its virtues, we would tolerate Kazanistan's theocratic elements; that is, take no steps to effect change there in a liberal direction. Rather, we should say that criticism itself can be a form of intolerance; a relatively weak form, maybe appropriate to this offense.

Liberal states have a moral responsibility to work toward the liberalization of illiberal states. We must not tolerate illiberal states. But only in extreme cases will our intolerance be expressed through coercive intervention. In most cases, strong intervention is not morally 
justified and would be ineffective besides. Instead, the means must be adapted to the offense. Rather than extend tolerance to an inevitably ad hoc class of illiberal states, as Rawls does, it is theoretically more satisfying to look at intolerance and its expressions on a continuum.

Nevertheless, the most egregious violations of human rights must be met with intolerance expressed by strong intervention that includes military operations.

\section{Final Remarks}

Before concluding, I consider one objection to my overall project in this essay, an objection which is quite independent from considerations of tolerance and pluralism. The objection is this: even the modest liberal hopes described here are too utopian. A fact of international relations is that states will do whatever is in their sovereign interests, period. Complaints about oppression abroad are really just an effort by liberal states to obtain a patina of moral respectability while pursuing their own interests. We criticize the secret prisons, government-created famine, and oppression in North Korea not because we really care about these issues, but because they are useful excuses for building international consensus against a regime which is developing ballistic missiles and threatening the West with nuclear war. Our world is one in which "power is its own justification, and there is no sin but failure". ${ }^{29}$

There is truth here. Although Rawls is convinced that democratic liberal states do not go to war against each other and that, by well-ordering all the world's peoples, a "democratic peace" is possible, he is too optimistic. Liberal democracy is a strong safeguard against aggressive war but it is no guarantee. What counts as self-defense is not always clear, and a terrorist group could use a well-ordered but internally weak state as a base to organize an attack against a liberal power. In that case, the powerful liberal state might argue the necessity of 
military intervention on grounds of self-defense; the target state's government, the argument would go, is simply unable to prevent its territory from being used by terrorists. Another example would be a major and unforeseen shock to the international order. An energy crisis might force liberal, decent, and to-that-point-well-behaved states into open conflict for scarce energy resources. In such a situation good will and concern for liberal values could yield to the realpolitik of protecting one's own people and interests.

That said, progress has been made on issues of human rights and global justice, and even if states cannot be expected to pursue these values without regard for their own parochial interests, there is no evidence that only self-interest plays a role in foreign policy. Governments are composed of persons, and inasmuch as they are educated to value human rights and global justice these facts of their character will be reflected in their policy choices. What a government wants for its people is based on what the members of that government consider important. Here I can only speak from my experience in the US national security community, but it seems to me that Western policymakers genuinely struggle to balance national interests with moral obligation. And when self-interest and morality diverge, only rarely is the former path chosen to the total exclusion of the latter. At the very least it can be said that concern for human rights is found overwhelmingly within liberal nations and expressed by liberal governments. ${ }^{30}$

For the foregoing reasons, Berlin was right to reckon a close connection between pluralism and liberalism. Indeed, there is a direct implication from pluralism to political liberalism. The empirical fact that we have in our society liberal lifestyles, illiberal ones, and every other kind under the sun is a reflection of the plural moral goods that exist. Pluralism is true, and it generates a moral obligation on states to tolerate a wide range of lifestyles within their borders. Just governments provide the conditions necessary for citizens to make their own 
choices about what is important. These conditions include basic social and political rights such as freedoms of expression and association, and a fair right of exit from illiberal groups.

Yet there is a sharp divide between tolerance at the domestic level and tolerance at the international level. Pluralism requires domestic tolerance but not tolerance toward illiberal states, and therefore the arguments of Gray and other philosophers inclined to say that liberalism is just one among a multitude of legitimate political doctrines (side-by-side with so-called "Asian values" and precepts found in fundamentalist Islam) do not succeed. ${ }^{31}$ For this reason, and the reasons given in $\S 4$, liberal states should not tolerate illiberal states. When deciding how to express our intolerance, policymakers have a range of options to choose from: personal messages to foreign leaders, diplomatic démarches, covert action, and, as a last resort, war. But in most cases the intervention will be mild, consonant with our intuition that mild illiberality should be met with a modest response.

The international march toward liberty still has a ways to go. But even if attained that is not the end but the beginning, as only then will all persons have the opportunity to pursue the lives that they think best, within a maximally tolerant political life.

\section{Tulane University}

I thank Kristen Currie, Jon Riley, Dave Shoemaker, Mike Valdman, and two anonymous referees for helpful suggestions on earlier drafts of this essay. I also wish to express my gratitude to the William Benjamin Smith Fund, the Edward Marshall Ballard Memorial Fund, Tulane's School of Liberal Arts, and the Murphy Institute for supporting this research. 
1 In his Four Essays on Liberty.

2 Some authors-e.g. Cohen, "What Toleration Is", and King, Toleration - have drawn a conceptual distinction between "tolerance" and "toleration". I use the terms interchangeably in this essay.

3 See King, Toleration, 21-24. The power criterion has traditionally been considered an essential element of tolerance, but see Williams, “An Impossible Virtue?”, for a dissenting view. $4 \quad$ For that, see King, Toleration.

5 Galston, Liberal Pluralism, 3.

6 We may distinguish between moral pluralism and political pluralism. Moral pluralism, as described here, is the idea that there are multiple moral goods. Political pluralism, as I shall understand it, is the idea that there are multiple legitimate ways that a person might pursue those goods. (See Mason, "Value Pluralism", for some other construals of political pluralism.) To see the difference, consider that we might condemn the illiberal Saudi government for two different reasons. First, we might say that the Saudi government is violating moral pluralism because it proscribes sexual expression, which is a moral good. Second, we might say that the Saudis violate political pluralism because, although they correctly acknowledge the moral good of spirituality, they proscribe some legitimate plans-of-life that pursue it (viz. non-Islamic ones). There are interesting conceptual issues involving the connection between the two which I will not investigate in this essay, and the distinction is frequently unmade in the literature; most philosophers, when they discuss "pluralism", seem to have in mind both moral and political pluralism. I follow in this usage, although at points, where it is relevant, I use the individual term. I thank an anonymous referee for several helpful comments on this matter.

$7 \quad$ See his "Need for a Pluralistic Emphasis" and "Political Implications of Ethical Pluralism".

$8 \quad$ Lamprecht, "Political Implications of Ethical Pluralism”, 225.

9 While the underlying connection between liberalism and pluralism is clear enough, it is not obvious how to interpret it—as, e.g., a logical implication or as a pragmatic fact. See Ferrell, "Isaiah Berlin", and Riley, “Interpreting Berlin's Liberalism”, for interpretations of Berlin's views on the matter.

10 See Gray's Enlightenment's Wake, Isaiah Berlin, and "Where Pluralists and Liberals Part Company". Also see Kekes's "Incompatibility of Liberalism and Pluralism".

11 Gray, "Where Pluralists and Liberals Part Company", 28.

12 Ibid., 26. Gray does concede the necessity of a "universal minimal morality", including, for example, prohibitions against murder and robbery - but this floor is far below the protections required by liberalism.

13 See Larmore, Morals of Modernity, and Rawls, Political Liberalism.

14 Mack, "The Quest for Liberal Pluralism", 222.

15 Larmore, Patterns of Moral Complexity, 129.

16 Gray, "Where Pluralists and Liberals Part Company", 28.

17 If I insist on trying to conjure up an image of arranging a life around negative liberty, as best I can tell that life would consist of incurring no obligations, entering into no contracts, relying on no one, and so on. It would be the life of a hermit. While this life is perfectly legitimate according to pluralism, it is not in fact a life based on negative liberty. It is, instead, a life based on independence (a genuine moral good). It cannot be based on negative liberty because it in fact constrains a person-from, for example, entering into contracts that are in his 
interest. But if the good involves constraint then it cannot, by definition, be tantamount to negative liberty.

18 Crowder, "Pluralism and Liberalism", 303. In that paper Crowder argues against the pluralism-to-liberalism implication, but he later comes around to accept it — see his "Two Valuepluralist Arguments".

19 Here are two salient questions: (1) must people living in liberal society refrain from criticizing each other's (legitimate) plans-of-life? And (2) must liberal governments refrain from criticizing their citizens" plans-of-life? The answer to both questions is "no". Although one way to be intolerant is to criticize, not all criticism is an expression of intolerance. We may criticize our peers (e.g. tell them not to devote their lives to the consumption of narcotics) while still tolerating their behavior as liberal pluralism requires. I thank an anonymous referee for raising these questions.

20 Gray, "Where Pluralists and Liberals Part Company", 30.

21 See Chege, Askew, and Liku, "An Assessment of the Alternative Rites Approach". I thank Emma Tuttleman-Kriegler for bringing this to my attention.

22 There are two major challenges facing the liberal in determining the extent to tolerate illiberal behavior within a state. First is what counts as a right of exit from a group. To my mind it must be deep and substantive - fair rather than formal — as argued for by Crowder, "Two Concepts of Liberal Pluralism", and Galston, Liberal Pluralism. Second is how to reckon the freedom of children; where to draw the line between the right of parents to raise their children as they see fit, and the children's right not to be disadvantaged by inept or extremist parents.

23 Gray, "Where Pluralists and Liberals Part Company", 24.

24 Arneson, "Value Pluralism Does Not Support Liberalism", 930.

25 Williams, "Introduction", xix.

26 "If liberal societies are to be commended on the pluralist ground that they harbour more genuine values than some illiberal societies, does it not follow that the human world will be still richer in value if it contains not only liberal societies but also illiberal regimes that shelter worthwhile forms of life that would otherwise perish?" Gray, Isaiah Berlin, 152.

27 Rawls, Law of Peoples, 59.

28 One historical candidate for a decent consultation hierarchy is the "millet system" of the Ottoman Empire. See Kymlicka, Contemporary Political Philosophy, 230-31.

29 Lamprecht, "Political Implications of Ethical Pluralism", 228.

30 Howard and Donnelly, "Human Dignity, Human Rights", go further and argue that only liberal regimes can show proper respect for human rights.

31 Sen, "Human Rights and Asian Values", argues that liberal theory is found in the Asian intellectual tradition, and Kubba, "Recognizing Pluralism", believes that authoritarian politics and political manipulation of the Koran are the principal sources of tension between Islam and liberalism. 


\section{References}

Arneson, Richard J. "Value Pluralism Does Not Support Liberalism: A Comment on William A. Galston's What Value Pluralism Means for Legal-Constitutional Orders.” San Diego Law Review 46, no. 4 (2009): 925-40.

Berlin, Isaiah. Four Essays on Liberty. Oxford: Oxford University Press, 1969.

Chege, Jane Njeri, Ian Askew, and Jennifer Liku. "An Assessment of the Alternative Rites Approach for Encouraging Abandonment of Female Genital Mutilation in Kenya.” Population Council, New York, 2001. http://pdf.usaid.gov/pdf_docs/PNACM865.pdf.

Cohen, Andrew Jason. "What Toleration Is.” Ethics 115, no. 1 (2004): 68-95.

Crowder, George. “Pluralism and Liberalism.” Political Studies 42, no. 2 (1994): 293-305.

------. “Two Concepts of Liberal Pluralism.” Political Theory 35, no. 2 (2007): 121-46.

------. “Two Value-pluralist Arguments for Liberalism.” Australian Journal of Political Science 37, no. 3 (2002): 457-73.

Ferrell, Jason. "Isaiah Berlin: Liberalism and Pluralism in Theory and Practice." Contemporary Political Theory 8, no. 3 (2009): 295-316.

Galston, William A. Liberal Pluralism: The Implications of Value Pluralism for Political Theory and Practice. New York: Cambridge University Press, 2002.

Gray, John. Enlightenment's Wake: Politics and Culture at the Close of the Modern Age. London: Routledge, 1995.

------. Isaiah Berlin. Princeton: Princeton University Press, 1996.

------. "Where Pluralists and Liberals Part Company." International Journal of Philosophical Studies 6, no. 1 (1998): 17-36. 
Howard, Rhoda E. and Jack Donnelly. "Human Dignity, Human Rights, and Political Regimes." American Political Science Review 80, no. 3 (1986): 801-17.

Kekes, John. "The Incompatibility of Liberalism and Pluralism." American Philosophical Quarterly 29, no. 2 (1992): 141-51.

King, Preston. Toleration. New York: St. Martin's Press, 1976.

Kubba, Laith. "Recognizing Pluralism.” Journal of Democracy 7, no. 2 (1996): 86-89.

Kymlicka, Will. Contemporary Political Philosophy: An Introduction, 2nd Edition. New York: Oxford University Press, 2002.

Lamprecht, Sterling P. "The Need for a Pluralistic Emphasis in Ethics.” Journal of Philosophy 17, no. 21 (1920): 561-72.

-----.. "Some Political Implications of Ethical Pluralism.” Journal of Philosophy 18, no. 8 (1921): 225-44.

Larmore, Charles E. The Morals of Modernity. Cambridge: Cambridge University Press, 1996.

------. Patterns of Moral Complexity. New York: Cambridge University Press, 1987.

Mack, Eric. "Isaiah Berlin and the Quest for Liberal Pluralism." Public Affairs Quarterly 7, no. 3 (1993): 215-30.

Mason, Elinor. "Value Pluralism." In Stanford Encyclopedia of Philosophy. Stanford University, 1997-. Article published July 29, 2011. http://plato.stanford.edu/archives/fall2011/entries/value-pluralism/.

Rawls, John. The Law of Peoples. Cambridge: Harvard University Press, 1999.

------. Political Liberalism. New York: Columbia University Press, 1996.

Riley, Jonathan. “Interpreting Berlin's Liberalism.” American Political Science Review 95, no. 2 (2001): 283-95. 
Sen, Amartya. "Human Rights and Asian Values." Lecture at the Carnegie Council on Ethics and International Affairs, New York, May 1997.

Williams, Bernard. Introduction to Concepts and Categories: Philosophical Essays by Isaiah Berlin, xiii-xx. Edited by Henry Hardy. London: Hogarth, 1978.

------. “Toleration: An Impossible Virtue?" In Toleration: An Elusive Virtue, edited by David Heyd, 18-27. Princeton: Princeton University Press, 1996. 